\title{
The influence of OPC and PPC on compressive strength of ALWA concrete
}

\author{
Fedya Diajeng Aryani ${ }^{1, *}$, Tavio ${ }^{1}, I_{\text {Gusti Putu Raka }}{ }^{1}$, and Puryanto ${ }^{2}$ \\ ${ }^{1}$ Department of Civil Engineering, Institut Teknologi Sepuluh Nopember (ITS), Surabaya, Indonesia \\ ${ }^{2}$ Department of Civil Engineering, Politeknik Negeri Sriwijaya, Palembang, Indonesia
}

\begin{abstract}
Lightweight concrete is one of the options used in construction in lieu of the traditional normal-weight concrete. Due to its lightweight, it provides lighter structural members and thus, it reduces the total weight of the structures. The reduction in weight resulting in the reduction of the seismic forces since its density is less than $1840 \mathrm{~kg} / \mathrm{m}^{3}$. Among all of the concrete constituents, coarse aggregate takes the highest portion of the concrete composition. To produce the lightweight characteristics, it requires innovation on the coarse aggregate to come up with low density of concrete. One possible way is to introduce the use of the artificial lightweight aggregate (ALWA). This study proposes the use of polystyrene as the main ingredient to form the ALWA. The ALWA concrete in the study also used two types of Portland cements, i.e. OPC and PPC. The ALWA introduced in the concrete comprises various percentages, namely $0 \%, 15 \%, 50 \%$, and $100 \%$ replacement to the coarse aggregate by volume. From the results of the study, it can be found that the compressive strength and the modulus of elasticity of concrete decreased with the increase of the percentage of the ALWA used to replace the natural coarse aggregate.
\end{abstract}

\section{Introduction}

Concrete is the most popular material which has been used for more than a century for structural purposes in construction [1-3]. Due to its heavyweight characteristic (around $2400 \mathrm{~kg} / \mathrm{m}^{3}$ ), the structural components with this kind of heavy materials such as concrete are very vulnerable against the seismic hazard [4-20]. To mitigate the damage of the structures due to the severe earthquake, the use of lighter concrete materials as one of the solutions become urgently necessary to be developed in the near future instead of the traditional normal-weight concrete. It is well known in concrete that the highest portion among all the concrete constituents is the coarse aggregate [1-3]. Hence, in order to come up with the lightweight concrete, the coarse aggregate is the main issue that needs to be replaced by the lighter one to reduce the self-weight of the structural components. A possible substitution to the natural coarse aggregate is by using the artificial lightweight aggregate (ALWA). The ALWA introduced in the study was the polystyrene. The polystyrene is a plastic material in the form of granules and having the characteristics of

* Corresponding author: fedyadiajeng@gmail.com 
low density and lightweight, and also its inter-grain space filled with air that can make a good insulation against the heat. In the past, several studies have shown that lightweight concrete has already involved the use of polystyrene in the concrete mixtures [21-23].

To create a good concrete, it certainly requires good binder such as cement. The most popular cement is the hydraulic cement which is normally a.k.a. Portland cement. Portland cement consists of several types in the market. However, three main products of Portland cement are the Ordinary Portland Cement (OPC), the Portland Composite Cement (PCC), and the Portland Pozzolana Cement (PPC). Despite there are three major types of cement in the market, the effect of OPC and PPC in concrete have been the major issue and investigated earlier [24].

This study discusses the impact of using the polystyrene ALWA as a replacement to the natural coarse aggregate in the concrete. The soluble polystyrene was formed to resemble the shape of the natural coarse aggregate of which its size can be designed and produced to satisfy a certain need of gradation or sieve analysis. The study also involved two types of cement, namely the OPC and PPC to investigate the effects of each type of cement. The percentages of ALWA replacement to the natural coarse aggregate used in concrete were $0 \%, 15 \%, 50 \%$, and $100 \%$ by total coarse aggregate volume.

\section{Methodology}

\subsection{Materials}

\subsubsection{Cement}

This study employed the effect of application of two different types of Portland cements, namely the OPC and PPC. The specific gravity of OPC used in the study was about 3.06 $\mathrm{gr} / \mathrm{cm}^{3}$, whereas for the PPC it was around $3.08 \mathrm{gr} / \mathrm{cm}^{3}$.

\subsection{Aggregates}

\subsubsection{Fine and coarse aggregates}

The natural fine aggregate used in the study can be categorized into gradation zone II. However, the natural coarse aggregate used has the maximum size of $20 \mathrm{~mm}$. The natural coarse aggregate used in the study was the crushed stone. Part or all of this aggregate has been replaced by ALWA. The results of the tests on the natural fine aggregate and crushed stone are given in Table 1.

Table 1. Test results of natural fine aggregate and crushed stone.

\begin{tabular}{|l|c|c|}
\hline \multicolumn{1}{|c|}{ Test } & Fine Aggregate & Crushed stone \\
\hline Absorption $(\%)$ & 1.58 & 1.08 \\
\hline Specific Gravity $\left(\mathrm{gr} / \mathrm{cm}^{3}\right)$ & 2.67 & 2.68 \\
\hline Density $\left(\mathrm{kg} / \mathrm{m}^{3}\right)$ & 1487.33 & 1513.33 \\
\hline Fine Modulus $(\%)$ & 2.40 & 6.64 \\
\hline
\end{tabular}




\subsubsection{Polystyrene artificial lightweight aggregate (ALWA)}

The ALWA used was a product of dissolved polystyrene in the acetone solution. The polystyrene used in the study was the by-product material obtained from industrial waste. In the production process, the polystyrene waste was dissolved in the acetone solution with the ratio of 1:1.9 by weight. The soluble polystyrene was then formed into granule shape such that it resembles the natural coarse aggregate with a maximum diameter of $20 \mathrm{~mm}$. Subsequently, the ALWA made from the polystyrene was left in the open air with room temperature for approximately three days to enable it to dry faster and produce the hardened texture. Figure 1 shows the ALWA product made from polystyrene. The tests conducted on ALWA made from polystyrene are listed in Table 2.

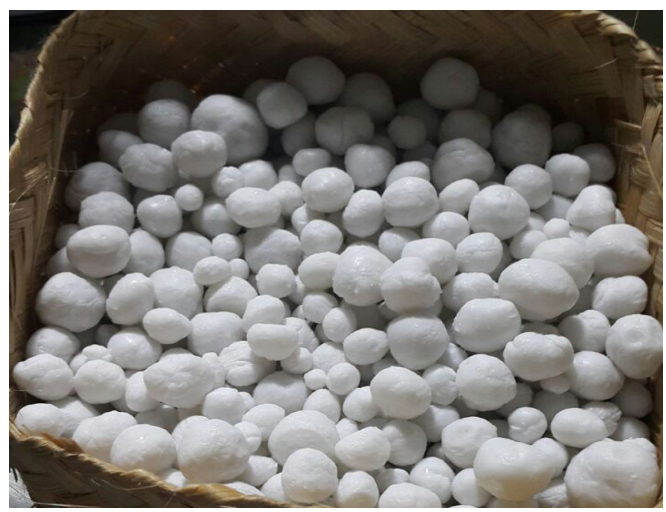

Fig. 1. ALWA made from polystyrene.

Table 2. Test results of ALWA made from polystyrene.

\begin{tabular}{|c|c|}
\hline Test & ALWA \\
\hline Specific Gravity $\left(\mathrm{gr} / \mathrm{cm}^{3}\right)$ & 0.75 \\
\hline Density $\left(\mathrm{kg} / \mathrm{m}^{3}\right)$ & 418.33 \\
\hline Fine Modulus $(\%)$ & 6.41 \\
\hline
\end{tabular}

\subsection{Mix design}

The study explored the impact of both OPC and PPC on concrete with ALWA. This is to observe the effect of each type of Portland cement on the compressive strength and the modulus of elasticity of concrete. The mix design method adopted in the study to find the composition of the concrete constituents was the development of environment (DOE) method. From the analysis, it can be found that the mixture proportion by weight ratio is 1 : $0.78: 1.33$ (cement : sand : crushed stone) and the water-cement ratio used was set as 0.3 . The percentages of ALWA made from polystyrene as a replacement to the natural coarse aggregate were $0 \%, 15 \%, 50 \%$, and $100 \%$ by volume of natural coarse aggregate. The mix design of the concrete is provided in Table 3. 
Table 3. Concrete mix design in $\mathrm{kg} / \mathrm{m}^{3}$.

\begin{tabular}{|c|c|c|c|c|c|c|c|}
\hline Cement & $\begin{array}{c}\text { Percentage of } \\
\text { ALWA } \\
\text { replacement } \\
\mathbf{( \% )}\end{array}$ & $\boldsymbol{w} / \boldsymbol{c}$ & Cement & Water & $\begin{array}{c}\text { Fine } \\
\text { Aggregat } \\
\mathbf{e}\end{array}$ & $\begin{array}{c}\text { Crushe } \\
\text { d Stone }\end{array}$ & $\begin{array}{c}\text { ALWA } \\
\text { made from } \\
\text { Polystyrene }\end{array}$ \\
\hline \multirow{3}{*}{$\begin{array}{c}\text { OPC } \\
\text { Concrete }\end{array}$} & 0 & 0.3 & 700 & 210 & 547 & 931 & 0.00 \\
\cline { 2 - 8 } & 15 & 0.3 & 700 & 210 & 547 & 791 & 38.60 \\
\cline { 2 - 8 } & 50 & 0.3 & 700 & 210 & 547 & 465 & 128.65 \\
\hline \multirow{3}{*}{$\begin{array}{c}\text { PPC } \\
\text { Concrete }\end{array}$} & 100 & 0.3 & 700 & 210 & 547 & 0 & 257.31 \\
\cline { 2 - 8 } & 0.3 & 700 & 210 & 547 & 931 & 0.00 \\
\cline { 2 - 8 } & 15 & 0.3 & 700 & 210 & 547 & 791 & 38.60 \\
\hline
\end{tabular}

\subsection{Specimens}

The test specimens used to obtain the compressive strength and the modulus of elasticity of concrete were $100 \times 200 \mathrm{~mm}$ concrete cylinders. Two types of Portland cements were used, namely the OPC and PPC, to form two sets of concrete cylinders. Every mixture comprised six test specimens in which consisted of three specimens each of OPC and PPC concretes. Table 4 represents the required number of test specimens for compressive strength as well as modulus of elasticity of concrete tests.

Table 4. Required number of test specimens for compressive strength and modulus of elasticity of concrete tests.

\begin{tabular}{|c|c|c|c|}
\hline \multirow{2}{*}{$\begin{array}{l}\text { Percentage of } \\
\text { ALWA } \\
\text { Replacement } \\
(\%)\end{array}$} & \multirow{2}{*}{$\begin{array}{l}\text { Types of } \\
\text { Cement }\end{array}$} & \multicolumn{2}{|c|}{$\begin{array}{c}\text { Required Number of Test } \\
\text { Specimens }\end{array}$} \\
\hline & & $\begin{array}{l}\text { Compressive } \\
\text { Strength }\end{array}$ & $\begin{array}{l}\text { Modulus of } \\
\text { Elasticity }\end{array}$ \\
\hline 0 & \multirow{4}{*}{ OPC } & \multicolumn{2}{|c|}{3} \\
\hline 15 & & \multicolumn{2}{|c|}{3} \\
\hline 50 & & \multicolumn{2}{|c|}{3} \\
\hline 100 & & \multicolumn{2}{|c|}{3} \\
\hline 0 & \multirow{4}{*}{ OPC } & \multicolumn{2}{|c|}{3} \\
\hline 15 & & \multicolumn{2}{|c|}{3} \\
\hline 50 & & \multicolumn{2}{|c|}{3} \\
\hline 100 & & \multicolumn{2}{|c|}{3} \\
\hline
\end{tabular}

\subsection{Test methods}

The compressive strength of concrete and the modulus of elasticity of concrete were tested at once using the Universal Testing Machine (UTM) to perform the compressive loading on the concrete cylinder specimens. The compressive strength test refers to the ASTM C39/C39M-18 [25]. The modulus of elasticity of concrete obtained from the tests were then compared with that of the ACI 318M-14 [26] for normal-weight concrete. All the tests were conducted at 28 days of age after the concrete casting. 


\section{Results and discussion}

\subsection{Density of concrete}

The densities of concrete were examined for both concretes using the OPC as well as the PPC. Table 5 shows the results of the tests.

Table 5. Densities of OPC and PPC Concrete.

\begin{tabular}{|c|c|c|}
\hline $\begin{array}{c}\text { Percentage } \\
\text { of ALWA } \\
\text { Replacement } \\
(\%)\end{array}$ & \multicolumn{2}{|c|}{ Density $\left(\mathbf{k g} / \mathbf{m}^{\mathbf{3}}\right)$} \\
\cline { 2 - 3 } & $\begin{array}{c}\text { OPC } \\
\text { Concrete }\end{array}$ & $\begin{array}{c}\text { PPC } \\
\text { Concrete }\end{array}$ \\
\hline 0 & 2461.60 & 2472.21 \\
\hline 15 & 2334.27 & 2344.88 \\
\hline 50 & 2026.57 & 2037.18 \\
\hline 100 & 1665.82 & 1761.31 \\
\hline
\end{tabular}

The increase of the percentage of ALWA replacement to the crushed stone of $15 \%$, $50 \%$, and $100 \%$ by volume of concrete has caused a reduction in densities of concrete using the PPC and the OPC of $6 \%, 18 \%$, and $29 \%$ and $5 \%, 18 \%$, and $33 \%$, respectively.

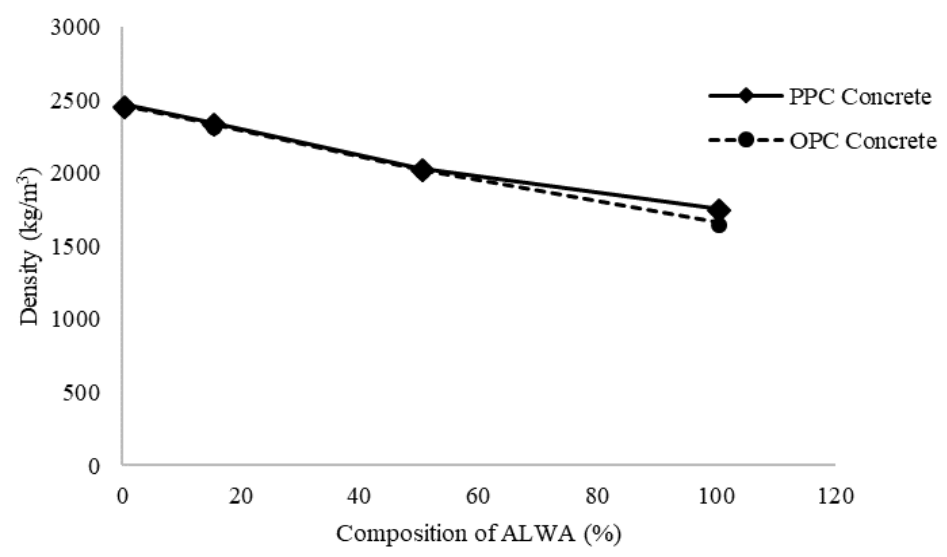

Fig. 2. The relationship between the percentage of ALWA replacement and the density of concrete using OPC and PPC.

The curves in Fig. 2 shows that the increase of percentage of ALWA replacement to the crushed stone has led to a proportional decrease in the concrete density. The reduction in density of concrete was due to the low density of ALWA made from polystyrene compared with that of crushed stone. The correlations between the densities of concretes using both OPC and PPC are nearly linear with the percentage of ALWA replacement to the crushed stone as shown in Fig. 2. From Fig. 2, the reduction in density of concrete can be found from the percentage of ALWA replacement to the crushed stone [27, 28].

\subsection{Compressive strength of concrete}

Table 6 shows the results of the compressive strength tests for both concrete with OPC and PPC. 
Table 6. Compressive strengths of OPC and PPC concretes.

\begin{tabular}{|c|c|c|}
\hline $\begin{array}{c}\text { Percentage of } \\
\text { ALWA } \\
\text { Replacement } \\
(\%)\end{array}$ & \multicolumn{2}{|c|}{$\begin{array}{c}\text { Compressive Strength }\left(\boldsymbol{f}^{\prime}\right) \\
(\mathbf{M P a})\end{array}$} \\
\cline { 2 - 3 } & $\begin{array}{c}\text { OPC } \\
\text { Concrete }\end{array}$ & $\begin{array}{c}\text { PPC } \\
\text { Concrete }\end{array}$ \\
\hline 0 & 43.05 & 28.65 \\
\hline 15 & 28.06 & 23.10 \\
\hline 50 & 19.23 & 19.02 \\
\hline 100 & 13.61 & 12.52 \\
\hline
\end{tabular}

From Table 6 , it can be seen that the compressive strengths of concretes $\left(f_{c}^{\prime}\right)$ using both OPC and PPC decrease when higher polystyrene ALWA was used in concrete as a replacement to the natural coarse aggregate. The substitution of $15 \%, 50 \%$, and $100 \%$ polystyrene-made ALWA has caused a reduction in the OPC concrete's compressive strength by as much as $22.23 \%, 36.03 \%$, and $57.89 \%$, and $22.23 \%, 36.03 \%$, and $57.89 \%$ for the PPC concrete. The optimum percentage of ALWA replacement to the crushed stone was found at about $15 \%$ with the compressive strengths of 28.06 and $23.10 \mathrm{MPa}$ for OPC and PPC concretes, respectively.

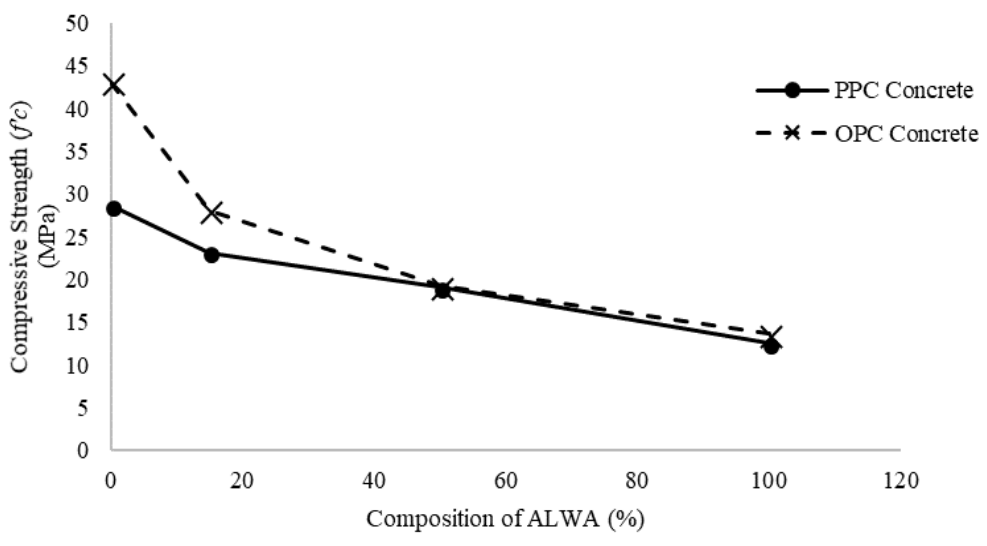

Fig. 3. The relationship between the percentage of ALWA replacement and the compressive strength of concrete $\left(f_{c}^{\prime}\right)$.

Figure 3 shows that the concrete's compressive strength is affected by the percentage of ALWA substitution. The increase of the use of polystyrene ALWA to replace the crushed stone leads to a proportional decrease in the compressive strength of concrete. The decrease in the compressive strength is suspected due to the smooth surface of polystyrene ALWA which makes it difficult to bond with the cement paste.

ACI $318 \mathrm{M}-14$ [26] provides the standard requirement for the compressive strength of seismic-resistant concrete structures and structural concrete of 20 and $17 \mathrm{MPa}$, respectively. As can be seen in Fig 3, to achieve the compressive strength of $20 \mathrm{MPa}$, the percentages of ALWA substitution to the crushed stone could be up to $41.62 \%$ and $46.93 \%$ for OPC and PPC concretes, respectively. To obtain the compressive strength of $17 \mathrm{MPa}$, the percentages of ALWA substitution are $69.83 \%$ and $65.56 \%$ for OPC and PPC concretes, respectively.

The optimum percentage of ALWA replacement to the crushed stone was at $15 \%$ with the compressive strength of $28.06 \mathrm{MPa}$. This case was for the OPC concrete. It was also found that the OPC concrete's compressive strength was greater than that of the PPC's concrete. The compressive strengths of concrete using polystyrene ALWA substitution of 
$0 \%, 15 \%, 50 \%$, and $100 \%$ were found about $33.45 \%, 17.66 \%, 1.06 \%$, and $8.01 \%$, respectively.

One of the findings of the study has confirmed the previous research [28] which found the use of polystyrene directly in concrete was optimum at around $15 \%$. The study which was carried out by Kamran and Mishra [24] shows that the compressive strength of concrete at 28 days of age using the OPC was higher than that using the PPC. The difference was reported as much as $17.6 \%$.

\subsection{Modulus of elasticity of concrete}

The modulus of elasticity of concrete is to define the relationship between the stress and the strain of concrete during the relatively elastic phase. The value of this modulus depends on the compressive strength of concrete, the loading type, as well as the materials used in producing the concrete. The ACI 318M-14 [26] sets that the modulus of elasticity of concrete can be found at the stress value of $45 \%$ of the maximum compressive strength value $\left(0.45 f_{c}^{\prime}\right)$. Table 7 shows the average values of the modulus of elasticity of concrete using both the OPC and PPC.

Table 7. Modulus of elasticity of concrete using OPC and PPC.

\begin{tabular}{|c|c|c|}
\hline $\begin{array}{c}\text { Percentage of } \\
\text { ALWA } \\
\begin{array}{c}\text { Replacement } \\
(\%)\end{array}\end{array}$ & \multicolumn{2}{|c|}{$\begin{array}{c}\text { Modulus of Elasticity }\left(\boldsymbol{E}_{\boldsymbol{c}}\right) \\
(\mathbf{M P a})\end{array}$} \\
\cline { 2 - 3 } & $\begin{array}{c}\text { OPC } \\
\text { Concrete }\end{array}$ & $\begin{array}{c}\text { PPC } \\
\text { Concrete }\end{array}$ \\
\hline 0 & $29,848.91$ & $24,150.44$ \\
\hline 15 & $21,496.72$ & $19,813.68$ \\
\hline 50 & $16,773.72$ & $15,990.72$ \\
\hline 100 & $11,532.99$ & $11,177.96$ \\
\hline
\end{tabular}

It can be seen in Table 7, when the polystyrene ALWA with the replacement percentages of $15 \%, 50 \%$, and $100 \%$ was used in concrete, the moduli of elasticity of OPC concrete were decreased by about $28 \%, 44 \%$, and $61 \%$ from the modulus of elasticity of OPC concrete without polystyrene ALWA. For PPC concrete, the decreases were also found by $18 \%, 34 \%$, and $54 \%$ from the PPC concrete without polystyrene ALWA. It can be concluded that the modulus of elasticity of concrete is reduced when more polystyrene ALWA is used as a replacement to the natural coarse aggregate. This could be due to the weak bond of the polystyrene ALWA with the cement paste in concrete [28].

Figure 4 shows that the modulus of elasticity reduces as the polystyrene ALWA increases. As for the comparison between the moduli of elasticity of concretes using the OPC and PPC and polystyrene ALWA, it was found that for replacement of $0 \%, 15 \%, 50 \%$, and $100 \%$, the moduli of elasticity of OPC concrete are greater than those of the PPC concrete by $19 \%, 8 \%, 5 \%$, and $3 \%$, respectively. The modulus of elasticity of concrete was significantly influenced by the materials used in making the concrete. Another important issue that needs serious attention during the compressive test is to assure that the surface of the specimens is horizontal, flat, and smooth to make sure that the load will be evenly distributed to the specimen's surface to avoid from premature failure. 


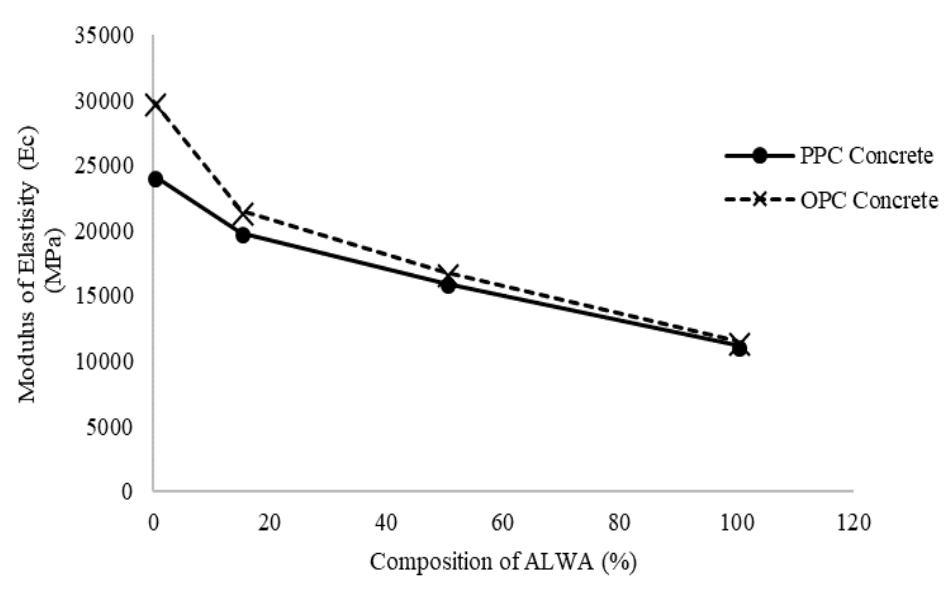

Fig. 4. The relationship between the percentage of ALWA replacement and the modulus of elasticity of concrete $\left(E_{c}\right)$.

\section{Conclusions}

From the study and discussion above, the following conclusions can be drawn:

1. The use of polystyrene ALWA as a replacement to the natural coarse aggregate has successfully reduced the density of concrete which was found to be less than 1840 $\mathrm{kg} / \mathrm{m}^{3}$ (lightweight concrete) when $100 \%$ polystyrene ALWA replacement was applied. The densities of OPC and PPC concretes were found to be $1665.82 \mathrm{~kg} / \mathrm{m}^{3}$ and $1761.31 \mathrm{~kg} / \mathrm{m}^{3}$, respectively. This is due to the density of polystyrene ALWA is lighter than the crushed stone.

2. The higher the percentage of the ALWA replacement to the natural coarse aggregate, the lower the compressive strength and modulus of elasticity of the concrete using both types of cements (OPC and PPC). This could be due to the smooth surface of the polystyrene ALWA which makes it difficult to bind with the cement paste.

3. The polystyrene ALWA can be introduced as a replacement to the natural coarse aggregate for structural concrete and seismic-resistant concrete structures with the percentages of replacement as much as $46.93 \%$ and $69.83 \%$ for the OPC concrete and as much as $41.62 \%$ and $65.56 \%$ for the PPC concrete.

4. The optimum percentage of ALWA as a replacement was found at about $15 \%$ in OPC concrete.

\section{References}

1. H. H. Ahmad, Tavio, Experimental Study of Cold-Bonded Artificial Lightweight Aggregate Concrete, AIP Conference Proceedings, American Institute of Physics, 1977, 030011-1-030011-8 (2018).

2. D. Raharjo, A. Subakti, Tavio, Mixed Concrete Optimization using Fly Ash, Silica Fume and Iron Slag on the SCC's Compressive Strength, Procedia Engineering, Elsevier, 54, 827-839 (2013).

3. D. T. A. Bramantio, I G. P. Raka, Tavio, Lightweight Aggregate Concrete using Pumice as Coarse Aggregate Partial Substitution, The $4^{\text {th }}$ National Conference of Civil Engineering (KoNTekS-4), Bali, Indonesia, S-173-S-180 (2010). 
4. Tavio, B. Kusuma, P. Suprobo, Experimental Behavior of Concrete Columns Confined by Welded Wire Fabric as Transverse Reinforcement under Axial Compression, ACI Structural Journal, American Concrete Institute, 109 (3), 339-348 (2012).

5. P. Pudjisuryadi, Tavio, P. Suprobo, Performance of Square Reinforced Concrete Columns Externally Confined by Steel Angle Collars under Combined Axial and Lateral Load, Procedia Engineering, Elsevier, 125, 1043-1049 (2015).

6. Tavio, P. Suprobo, B. Kusuma, Ductility of Confined Reinforced Concrete Columns with Welded Reinforcement Grids, Excellence in Concrete Construction through Innovation-Proceedings of the International Conference on Concrete Construction, CRC Press, Taylor and Francis Group, London, UK, 339-344 (2009).

7. B. Kusuma, Tavio, P. Suprobo, Axial Load Behavior of Concrete Columns with Welded Wire Fabric as Transverse Reinforcement, Procedia Engineering, Elsevier, 14, 2039-2047 (2011).

8. Tavio, B. Kusuma, P. Suprobo., Investigation of Stress-Strain Models for Confinement of Concrete by Welded Wire Fabric, Procedia Engineering, Elsevier, 14, 2031-2038 (2011).

9. Tavio, B. Kusuma, Stress-Strain Model for High-Strength Concrete Confined by Welded Wire Fabric, Journal of Materials in Civil Engineering, American Society of Civil Engineers, 21 (1), 40-45 (2009).

10. Tavio, R. Anggraini, I G. P. Raka, Agustiar, Tensile Strength/Yield Strength (TS/YS) Ratios of High-Strength Steel (HSS) Reinforcing Bars, AIP Conference Proceedings, American Institute of Physics, 1964, 020036-1-020036-8 (2018).

11. Tavio, P. Suprobo, B. Kusuma, Strength and Ductility Enhancement of Reinforced HSC Columns Confined with High-Strength Transverse Steel, Proceedings of the Eleventh East Asia-Pacific Conference on Structural Engineering and Construction (EASEC-11), Taipei, Taiwan, 350-351 (2008).

12. R. Anggraini, Tavio, I G. P. Raka, Agustiar, Stress-Strain Relationship of HighStrength Steel (HSS) Reinforcing Bars, AIP Conference Proceedings, American Institute of Physics, 1964, 020025-1-020025-8 (2018).

13. P. Pudjisuryadi, Tavio, P. Suprobo, Axial Compressive Behavior of Square Concrete Columns Externally Collared by Light Structural Steel Angle Sections, International Journal of Applied Engineering Research, Research India Publications, 11 (7), 46554666 (2016).

14. B. Sabariman, A. Soehardjono, Wisnumurti, A. Wibowo, Tavio, Stress-Strain Behavior of Steel Fiber-Reinforced Concrete Cylinders Spirally Confined with Steel Bars, Advances in Civil Engineering, Hindawi, 2018, 1-8 (2018).

15. M. D. Astawa, I G. P. Raka, Tavio, Moment Contribution Capacity of Tendon Prestressed Partial on Concrete Beam-Column Joint Interior According to Provisions ACI 318-2008 Chapter 21.5.2.5(c) Due to Cyclic Lateral Loads, MATEC Web of Conferences, EDP Sciences, 58 (04005), 1-8 (2016).

16. Tavio, Parmo, A Proposed Clamp System for Mechanical Connection of Reinforcing Steel Bars, International Journal of Applied Engineering Research, Research India Publications, 11 (11), 7355-7361 (2016).

17. I G. P. Raka, Tavio, M. D. Astawa, State-of-the-Art Report on Partially-Prestressed Concrete Earthquake-Resistant Building Structures for Highly-Seismic Region, Procedia Engineering, Elsevier, 95, 43-53 (2014). 
18. Tavio, S. Teng, Effective Torsional Rigidity of Reinforced Concrete Members, ACI Structural Journal, American Concrete Institute, 101 (2), 252-260 (2004).

19. Tavio, Interactive Mechanical Model for Shear Strength of Deep Beams, Journal of Structural Engineering, American Society of Structural Engineers, 132 (5), 826 -827 (2006).

20. M. D. Astawa, Tavio, I G. P. Raka, Ductile Structure Framework of Earthquake Resistant of High-Rise Building on Exterior Beam-Column Joint with the Partial Prestressed Concrete Beam-Column Reinforced Concrete, Procedia Engineering, Elsevier, 54, 413-427 (2013).

21. C. A. Cadere, M. Barbuta, B. Rosca, A. A. Serbanoiu, A. Burlacu, I. Oancea, Engineering Properties of Concrete with Polystyrene Granules, Procedia Manufacturing, Elsevier, 22, 288-293 (2018).

22. B. Chen, J. Liu, Properties of Lightweight Expanded Polystyrene Concrete Reinforced with Fiber, Cement and Concrete Research, 34, 1259-1263 (2004).

23. A. Paranje, P. Kulkarni, Experimental Investigation on Styrofoam Based Concrete, International Journal of Mechanical and Production Engineering, 5 (12), 56-61 (2017).

24. M. Kamran, M. Mishra, Behavior of Self-Compacting Concrete using PPC and OPC with Different Proportions of Fly Ash, International Journal of Research in Engineering and Technology, 3 (9), 342-345 (2014).

25. ASTM Subcommittee C09.61, Standard Test Method for Compressive Strength of Cylindrical Concrete Specimens (ASTM C39/C39M-18), ASTM International (2018).

26. ACI Committee 318, Building Code Requirements for Structural Concrete (ACI 318M-14) and Commentary (ACI 318RM-14), American Concrete Institute, 519 (2014).

27. Y. Xu, L. Jiang, J. Xu, Y. Li, Mechanical Properties of Expanded Polystyrene Lightweight Aggregate Concrete and Brick, Construction and Building Materials, 27, 32-38 (2012).

28. A. Sadrmomtazi, M. A. M. Langeroudi, A. Fasihi, A. K. Haghi, An Investigation on Effect of using PP Fibers and Different Cementitious Materials on Mechanical Properties of EPS Concrete, International Council for Research and Innovation in Building and Construction, CD08-005, 1035-1044 (2009). 